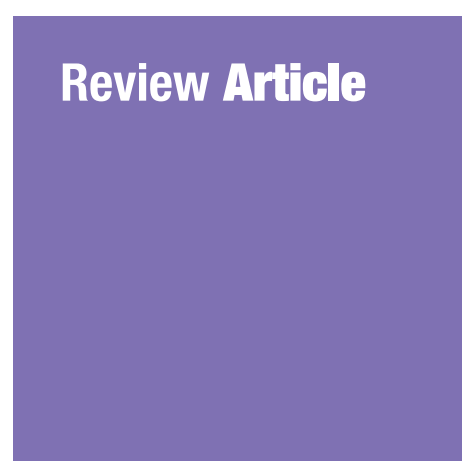

Submitted: 1 Nov 2017

Accepted: 3 Jul 2018

Online: 28 Jun 2019

\section{Prevalence of HIV, Hepatitis B and C Virus Co-infections among Iranian High-Risk Groups: A Systematic Review and Meta- Analysis}

\author{
Amir Almasi Hashiani ${ }^{1}$, Farzin Sadeghi' ${ }^{2}$, Erfan Ayubi ${ }^{3}$, Shahab \\ REZAEIAN ${ }^{4}$, Yousef Moradi ${ }^{5}$, Kamyar Mansori ${ }^{6}$, Behzad \\ GHolamaliel $^{7}$, Abolfazl Mohammadbeigl ${ }^{8}$, Salman KhaZAEI ${ }^{9}$
}

1 Department of Epidemiology, Arak University of Medical Sciences, Arak, Iran and Traditional and Complementary Medicine Research Center, Arak University of Medical Sciences, Arak, Iran

2 Infectious Diseases \& Tropical Medicine Research Center, Babol University of Medical Sciences, Babol, Iran

3 Department of Community Medicine, School of Medicine, Zahedan University of Medical Sciences, Zahedan, Iran

4 Research Center for Environmental Determinants of Health, Kermanshah University of Medical Sciences, Kermanshah, Iran

5 Pars Advanced and Minimally Invasive Medical Manners Research Center, Pars Hospital, Iran University of Medical Sciences, Tehran, Iran

6 Department of Epidemiology and Biostatistics, School of Medicine, Zanjan University of Medical Sciences, Zanjan, Iran

7 Department of Public Health, School of Public Health, Hamadan University of Medical Sciences, Hamadan, Iran

8 Research Center of Gastroenterology and Hepatology, Qom University of Medical Sciences, Qom, Iran

9 Research Center for Health Sciences, Hamadan University of Medical Sciences, Hamadan, Iran

To cite this article: Almasi Hashiani A, Sadeghi F, Ayubi E, Rezaeian S, Moradi Y, Mansori K, Gholamaliei B, Mohammadbeigi A, Khazaei S. Prevalence of HIV, hepatitis B and C virus co-infections among Iranian high-risk groups: a systematic review and meta-analysis. Malays J Med Sci. 2019;26(3):37-48. https://doi.org/10.21315/ mjms2019.26.3.3

To link to this article: https://doi.org/10.21315/mjms2019.26.3.3

\title{
Abstract
}

Co-infection with hepatitis B and C among HIV infected patients are prevalent among high-risk populations. This meta-analysis aimed to estimate the prevalence of HIV, HCV and HBV co-infections among high-risk populations in Iran.

We systematically searched the national and international electronic databases until 2016. The primary outcome was the prevalence of HIV, HBV, HCV and HIV co-infections in different high-risk populations in Iran. All English and Persian studies conducted on Iranian high-risk groups were included in the study. The review was reported based on PRISMA guidelines and data were analysed at $95 \%$ confidence level using random effect models. 
Overall, 916 relevant papers were recognised and 14 articles were included in the metaanalysis. The pooled estimates of $\mathrm{HBV} / \mathrm{HCV}, \mathrm{HCV} / \mathrm{HIV}, \mathrm{HBV} / \mathrm{HIV}$ and $\mathrm{HBV} / \mathrm{HCV} / \mathrm{HIV}$ were 1.3\% (95\%CI: 0.5-2.1), 16.3\% (95\%CI: 1.1-31.6), 0.5\% (95\%CI: o-1.4) and 0.5\% (95\%CI: 0.2-0.8), respectively. Based on subgroup analysis, there was a higher proportion of all co-infections from the years 2010-2016 as compared to that of the years 2003-2009.

Our results highlighted that $\mathrm{HCV} / \mathrm{HIV}$ co-infection in Iranian high-risk groups including injection drug users (IDUs) and prisoners is common. In addition, the increasing trend of coinfections should be considered alarming for policymakers.

Keywords: HIV infection, hepatitis $B$, hepatitis $C$, co-infection

\section{Introduction}

The prevalence and burden of HIV infection varies widely among developed and developing countries (1). This proportion also varies across the different regions in each country. HIV infection is a major public health problem and is also a major cause of morbidity and mortality in developing countries (2). Accordingly, it is suggested that a high-impact prevention approach should be conducted in communities with a high proportion of HIV infection (3).

Co-infection with hepatitis B and C among HIV infection patients are more prevalent (4) especially among high-risk groups such as prisoners and people who inject drugs (PWID) $(5,6)$. In addition, these infections have been reported as one of the most important causes of liver-related morbidity and mortality worldwide $(7,8)$.

It has been recently shown that there is a relatively low prevalence of HIV infection and other blood-borne viral infections in the Iranian general population. This low prevalence is attributable to widespread prevention strategies across the country e.g. harm reduction services, methadone maintenance therapy, public awareness on routes of infection transmission, and free HIV testing and counseling services. On the other hand, despite prevention strategies such as HCV screening in HIV-infected patients and high-risk groups, Iran is faced with an HIV epidemic among high-risk populations e.g. PWID, with a prevalence of $18.4 \%$ (9).

Several studies were conducted in Iran in order to estimate the prevalence of HIV, HBV and HCV co-infections among prisoners and other high-risk groups; however, the results are inconsistent and the actual prevalence rate among high-risk population is unclear. Thus, the aim of this meta-analysis was to estimate the prevalence rate of HIV, HCV and HBV coinfections among high risk populations in Iran.

\section{Material and Methods}

\section{Search Strategy}

Two investigators searched the following international electronic bibliographic databases including: PubMed, Scopus and ISI; and national databases including: Magiran, Iranmedex and SID from year 2000 to end of year 2016. A manual search of the reference lists of published articles was also performed. This review was performed in accordance with the PRISMA (Preferred Reporting Items for Systematic Reviews and Meta-Analyses) statement issued in 2009 (10).

Key search terms included terminology for prostitute; FSW or sex worker; intravenous drug users; drug addicts; IDU or injection drug users; prisoner; jail; inmate or prison; HIV or human immunodeficiency virus, HBV or hepatitis B, HCV or Hepatitis C or blood borne infection; and Iran.

All English and Persian papers that were conducted on Iranian high-risk groups to determine the prevalence of HIV, HCV and HBV infection were included in the study. Papers with no relevant data, duplicate papers, review articles, randomised clinical trials and no highrisk group studies were excluded from the metaanalysis.

We defined sex worker as exchanging sex for money, drugs, or goods (11). Also IDUs were defined as people who inject narcotic substances into the body with a hollow needle and a syringe which is pierced through the skin into the body, usually intravenously (12). We included English or Farsi cross-sectional articles on Iranian highrisk groups that determined HBV, HCV and HIV infection in patients based on the laboratory criteria according to national guideline definitions. Therefore, measured HIV (HIV Ab) and co-infections such as HBV (HBs Ag) or HCV ( $\mathrm{HCV} \mathrm{Ab}$ ) infection with confirmatory lab tests were included. The articles with no relevant data or other design were excluded. 


\section{Data Extraction and Quality Assessment}

Two independent authors (AAH and SK) reviewed the retrieved studies and the following information were extracted: (i) name of the first author, (ii) publication year and location of study, (iii) total sample size, (iv) the reported prevalence of co-infection, (v) recruitment setting, (vi) recruitment method, (vii) age group and (viii) high risk group (IDUs, FSWs, or prisoners). Duplications were identified by comparing detailed study characteristics, including author names, study period, study location, the number of infection cases, and the sample size. If two publications were found to be from the same data source, only the earlier publication was included.

The Kappa agreement (95\%) was used to identify the inter-authors reliability. The value of Kappa over 0.75 indicates excellent interauthors reliability or inter-authors agreement. The third author (AAH) was considered as arbiter to resolve any disagreements. The quality of the studies was evaluated by two independent reviewers (AAH and SK) according to the Newcastle-Ottawa scale (13).

\section{Statistical Analysis}

Meta-analyses were carried out using Stata software, version 12 (Stata Corp, College Station, TX, USA). We did meta-analysis for each $\mathrm{HIV}, \mathrm{HCV}, \mathrm{HBV}, \mathrm{HBV} / \mathrm{HCV}, \mathrm{HBV} / \mathrm{HIV}, \mathrm{HCV} /$ $\mathrm{HIV}$ and $\mathrm{HBV} / \mathrm{HCV} / \mathrm{HIV}$ prevalence in every subpopulation. The variance of each study was calculated through the variance of the binomial distribution given that the prevalence rate had a binomial distribution. Then, each study was given a weight, which was inversely proportional to the variance.

The analysis of heterogeneity was performed using the Cochran's Q test (with $P$-value $<0.10)$ and it was quantified by the $\mathrm{I}^{2}$ statistic. An $\mathrm{I}^{2}$ value of $50 \%$ or greater and/ or a Q-statistic value of $P<0.05$ suggest the presence of heterogeneity, which means that differences in the point estimates reported by the included studies are greater than one would expect due to chance alone. Thus, pooling of these data using a fixed-effects meta-analysis would be invalid. Tau-squared $\left(\mathrm{t}^{2}\right.$ or $\left.\mathrm{Tau}^{2}\right)$ statistic and Egger's linear regression test were used to explore the between-study variance and to investigate publication bias, respectively. Subgroups analysis was conducted on the basis of infection type, high-risk group and geographical regions, and to examine the impact of moderator variables on prevalence rate metaregression was used.

In order to calculate a weighted mean estimate of prevalence for mentioned infections across included studies, prevalence estimates by each study were pooled using a random-effects meta-analysis model at a confidence level of $95 \%$.

\section{Results}

Figure 1 depicted the process of the search and study selection (10). In total, 916 relevant papers were recognised from the searches in different national and international databases. After excluding duplicates, 566 papers remained and then we disqualified 552 papers by screening titles and abstracts. Finally, 14 articles were included in the meta-analysis (14-27).

\section{Study Characteristics}

The characteristics of primary studies that were included in this meta-analysis are shown in Tables 1 and 2. These papers were published between 2003 and 2016 with various sample sizes which ranged from 70 to 1444 , with a total of 6218 cases with high-risk behaviour including IDUs (six studies), prisoners (six studies), HIV positive (one study), and drug addicts (one study). 


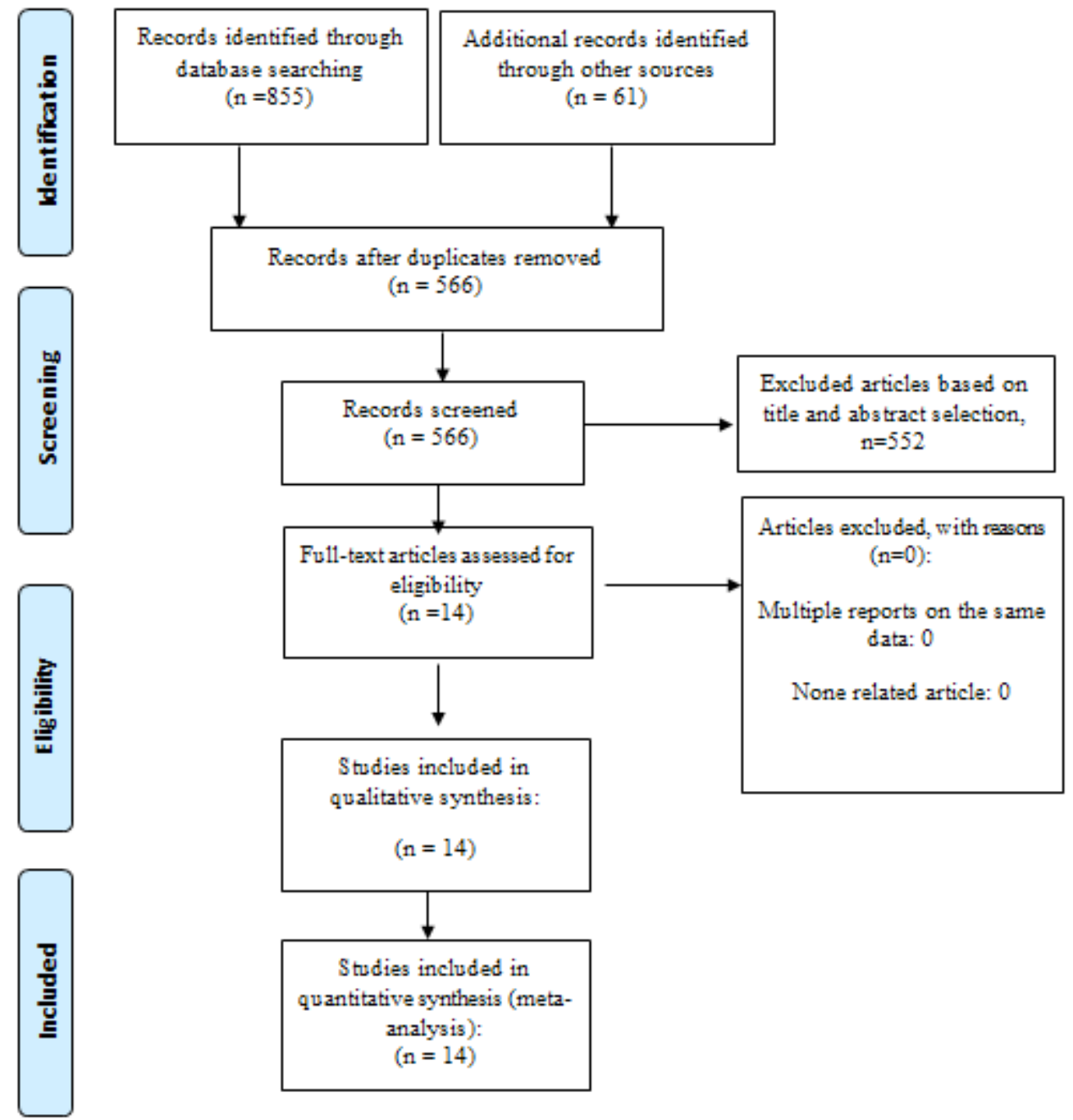

Figure 1. Flow diagram of study selection

Table 1. Description of the studies included in the meta-analysis

\begin{tabular}{|c|c|c|c|c|c|c|c|}
\hline First author & Year & Location & $\begin{array}{l}\text { High risk } \\
\text { group }\end{array}$ & $\begin{array}{l}\text { Recruitment } \\
\text { setting }\end{array}$ & $\begin{array}{l}\text { Recruitment } \\
\text { method }\end{array}$ & Age group & Sex \\
\hline Khani M et al. & 2003 & Zanjan & Prisoners & Prison & Unknown & $33.7 \pm 10.2$ & Male \\
\hline Azarkar Z et al. & 2006 & Birjand & Prisoner & Prison & $\begin{array}{l}\text { Stratified } \\
\text { random } \\
\text { sampling }\end{array}$ & $34.1 \pm 11.7$ & Both \\
\hline Zamani S et al. & 2007 & Tehran & IDU & $\begin{array}{l}\text { DIC and } \\
\text { neighboring } \\
\text { parks and } \\
\text { streets }\end{array}$ & Unknown & median 32 & Both \\
\hline $\begin{array}{l}\text { Pourahmad M } \\
\text { et al. }\end{array}$ & 2007 & $\begin{array}{l}\text { Esfahan, } \\
\text { Chaharmahal } \\
\text { and Lorestan }\end{array}$ & Prisoner & Prison & Unknown & $25-60$ & Male \\
\hline $\begin{array}{l}\text { Aminzadeh } \mathrm{Z} \text { et } \\
\text { al. }\end{array}$ & 2007 & Tehran & IDU & Hospital & Volunteers & $34.4 \pm 9.6$ & Male \\
\hline Alavi SM et al. & 2009 & Ahvaz & IDU & Hospitalized & Unknown & $26.3 \pm 5.7$ & Both \\
\hline
\end{tabular}


Review Article | HIV, HBV \& HCV co-infections in high risk groups

Table 1. (continued)

\begin{tabular}{|c|c|c|c|c|c|c|c|}
\hline First author & Year & Location & $\begin{array}{l}\text { High risk } \\
\text { group }\end{array}$ & $\begin{array}{l}\text { Recruitment } \\
\text { setting }\end{array}$ & $\begin{array}{l}\text { Recruitment } \\
\text { method }\end{array}$ & Age group & Sex \\
\hline Sharif $\mathrm{M}$ et al. & 2009 & Kashan & IDU & Hospitalized & Volunteers & $36.5 \pm 10.2$ & Both \\
\hline Hosseini M et al. & 2010 & Tehran & IDU & $\begin{array}{l}\text { temporary } \\
\text { detention } \\
\text { center }\end{array}$ & Census & NA & Male \\
\hline Sofian M et al. & 2012 & Arak & Prisoner & Prison & Census & $30.7 \pm 5.9$ & Male \\
\hline $\begin{array}{l}\text { Nokhodian Z et } \\
\text { al. }\end{array}$ & 2012 & Isfahan & Prisoner & Prison & Census & $\begin{array}{l}34.54 \pm \\
11.2\end{array}$ & Female \\
\hline Alipour A et al. & 2013 & Shiraz & $\begin{array}{l}\text { HIV } \\
\text { Possitive }\end{array}$ & $\begin{array}{l}\text { Counselling } \\
\text { Centre for } \\
\text { Behav Dis }\end{array}$ & Census & $38.4 \pm 9.2$ & Both \\
\hline Ziaee $\mathrm{M}$ et al. & 2014 & $\begin{array}{l}\text { Southern } \\
\text { Khorasan }\end{array}$ & Prisoner & Prison & $\begin{array}{l}\text { random } \\
\text { sampling }\end{array}$ & $34 \cdot 7 \pm 11.4$ & Both \\
\hline Ramezani A et al. & 2014 & Arak & IDU & MMT center & Census & $\begin{array}{l}\text { median } \\
33 \cdot 3 \\
(\mathrm{R}: 17-58)\end{array}$ & Male \\
\hline Norouzian H et al. & 2016 & Lorestan & Addicts & $\begin{array}{l}\text { Drug } \\
\text { Treatment } \\
\text { Centers }\end{array}$ & Volunteers & 31.7 & Both \\
\hline
\end{tabular}

Table 2. Description of the studies included in the meta-analysis

\begin{tabular}{|c|c|c|c|c|c|c|c|c|c|}
\hline First author & $\begin{array}{l}\text { Sample } \\
\text { size }\end{array}$ & $\begin{array}{c}\text { HCV/ } \\
\text { HIV (N) }\end{array}$ & $\begin{array}{c}\text { HCV/ } \\
\text { HIV (\%) }\end{array}$ & $\begin{array}{l}\text { HBV/ } \\
\text { HIV (N) }\end{array}$ & $\begin{array}{c}\text { HBV/ } \\
\text { HIV (\%) }\end{array}$ & $\begin{array}{c}\text { HBV/ } \\
\text { HCV (N) }\end{array}$ & $\begin{array}{c}\text { HBV/ } \\
\text { HCV (\%) }\end{array}$ & $\begin{array}{c}\text { HBV/ } \\
\text { HCV/ } \\
\text { HIV (N) }\end{array}$ & $\begin{array}{c}\text { HBV/ } \\
\text { HCV/ } \\
\text { HIV (\%) }\end{array}$ \\
\hline Khani M et al. & 346 & 4 & 1.16 & 1 & 0.28 & 7 & 2.02 & 1 & 0.29 \\
\hline Azarkar Z et al. & 400 & - & - & - & - & 1 & 0.25 & - & - \\
\hline Zamani S et al. & 202 & 19 & 9.41 & - & - & - & - & - & - \\
\hline $\begin{array}{l}\text { Pourahmad M } \\
\text { et al. }\end{array}$ & 1431 & - & - & - & - & - & - & 8 & 0.56 \\
\hline $\begin{array}{l}\text { Aminzadeh Z } \\
\text { et al. }\end{array}$ & 70 & 13 & 18.57 & 3 & 4.28 & 2 & 2.86 & 1 & 1.43 \\
\hline Alavi SM et al. & 142 & 12 & 8.45 & - & - & 3 & 2.11 & - & - \\
\hline Sharif M et al. & 200 & - & - & - & - & 2 & 1.00 & o & o \\
\hline Hosseini M et al. & 417 & 100 & 23.98 & - & - & - & - & - & - \\
\hline Sofian M et al. & 153 & 8 & 5.23 & 3 & 1.96 & 9 & 5.88 & 2 & 1.31 \\
\hline $\begin{array}{l}\text { Nokhodian Z } \\
\text { et al. }\end{array}$ & 161 & - & - & - & - & o & o & - & - \\
\hline Alipour A et al. & 1,444 & 1,132 & 78.39 & - & - & - & - & - & - \\
\hline Ziaee M et al. & 881 & 1 & 0.11 & - & - & 6 & 0.68 & - & - \\
\hline Ramezani A et al. & 100 & 15 & 15.00 & - & - & 6 & 6.00 & 5 & 5.00 \\
\hline $\begin{array}{l}\text { Norouzian } \mathrm{H} \\
\text { et al. }\end{array}$ & 271 & 8 & 2.95 & - & - & 3 & 1.11 & 1 & 0.37 \\
\hline
\end{tabular}




\section{Evaluation of Heterogeneity and Meta-Analysis}

The pooled estimate of $\mathrm{HBV} / \mathrm{HCV}, \mathrm{HCV} /$ $\mathrm{HIV}, \mathrm{HBV} / \mathrm{HIV}$ and $\mathrm{HBV} / \mathrm{HCV} / \mathrm{HIV}$ were $1.3 \%$ (95\%CI: $0.5-2.1$ ), $16.3 \%$ (95\%CI: 1.1-31.6), 0.5\% (95\%CI: $0-1.4$ ) and $0.5 \%$ (95\%CI: $0.2-0.8$ ), respectively (Table 3 and Figures 2, 3, 4 and 5). The results of Cochran's Q test and $\mathrm{I}^{2}$ statistics suggested a significant heterogeneity among the included studies. Considering significant heterogeneity between studies, we used a random effect model and we also performed a subgroup analysis based on time period (Table 4).

\section{Publication Bias}

On the basis of the Begg's test, there were some evidence of publication bias in $\mathrm{HBV} / \mathrm{HCV}$ co-infection $(P=0.012)$, whereas there was no publication bias in HCV/HIV $(P=0.176)$, HBV/ HIV $(P=0.117)$ and HBV/HCV/HIV $(P=0.091)$ co-infections. Also, the results of funnel plot showed that there was some asymmetry in the point estimate of published papers.

\section{Sensitivity Analysis}

The prevalence of HCV/HIV co-infection in the Alipour et al. (27) study was very high (78\%). When we excluded their study, the pooled prevalence of $\mathrm{HCV} / \mathrm{HIV}$ co-infection decreased to $8.33 \%$ (95\%CI: $5.02-11.64$ ) from $16.3 \%$ (95\%CI: 1.1-31.6), and in the studies between 2010 and 2016 it was decreased to 9.05\% (95\%CI: 2.54-15.5) while before excluding Alipour et al., it was 21.0\% (95\%CI: 0-49.1).

\section{Subgroup Analysis}

Based on the results, there was considerable heterogeneity between studies and therefore subgroup analysis based on time period (20032009 and 2010-2016) was done for all coinfections and their results were displayed in Table 4. The results showed that the pooled prevalence of all co-infections in the second period (2010-2016) were higher compared to the first period.

Table 3. Summary of meta-analysis results

\begin{tabular}{lllllll}
\multirow{2}{*}{ Comorbidities } & \multicolumn{3}{c}{ Meta-analysis } & \multicolumn{3}{c}{ Heterogeneity } \\
& Prevalence & $\mathbf{9 5 \% C I}$ & Model & Statistic & P-value & $\mathbf{I}^{2}$ \\
HBV/HCV & $1.3 \%$ & $0.5-2.1$ & Random & 15.99 & 0.043 & $50.0 \%$ \\
HCV/HIV & $16.3 \%$ & $1.1-31.6$ & Random & 5237.71 & 0.001 & $99.8 \%$ \\
HBV/HIV & $0.5 \%$ & $0-1.4$ & Fixed & 3.01 & 0.222 & $33.6 \%$ \\
HBV/HCV/HIV & $0.5 \%$ & $0.2-0.8$ & Fixed & 5.07 & 0.535 & $0.0 \%$ \\
\hline
\end{tabular}


Review Article | HIV, HBV \& HCV co-infections in high risk groups

Study
ID

Figure 2. Forest plot showing prevalence of $\mathrm{HBV} / \mathrm{HCV}$ comorbidities in the Iranian high- risk group

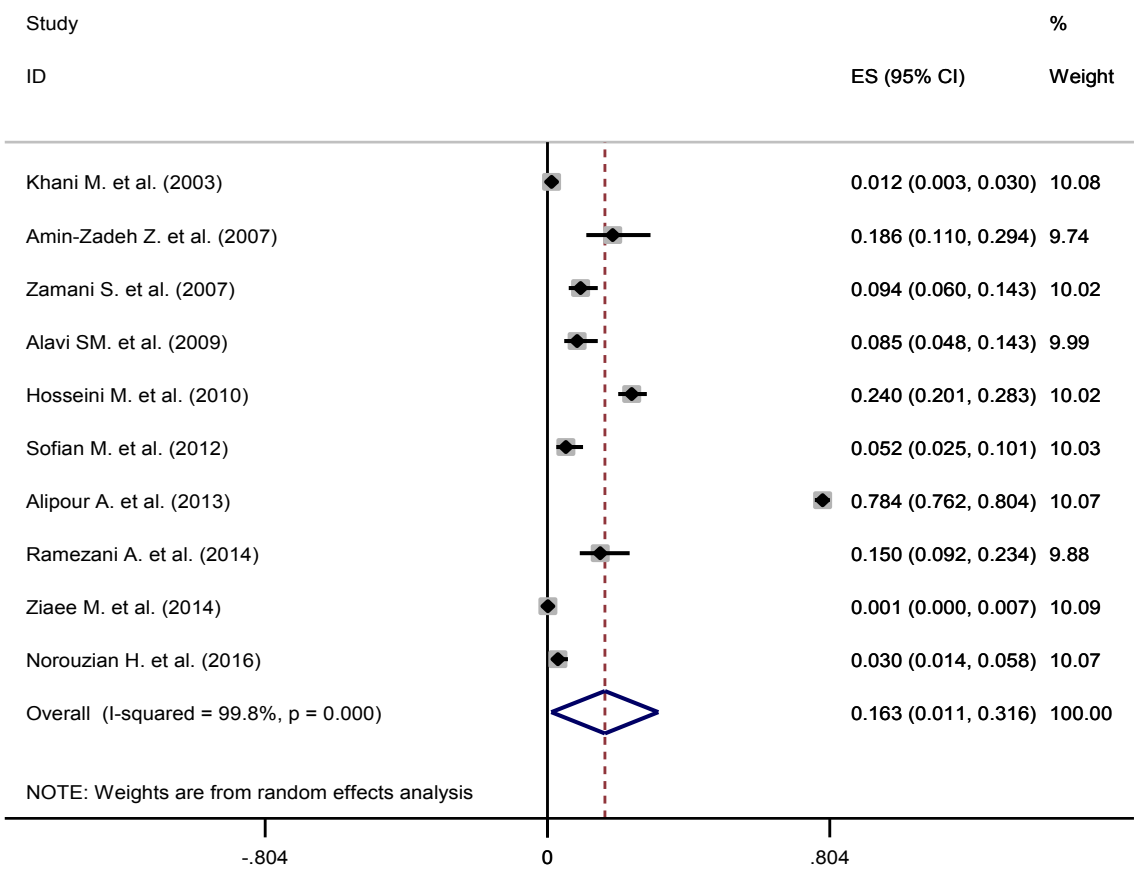

Figure 3. Forest plot showing prevalence of HCV/HIV comorbidities in the Iranian high risk group 
Study

ID
$\%$

ES $(95 \% \mathrm{Cl})$

Weight

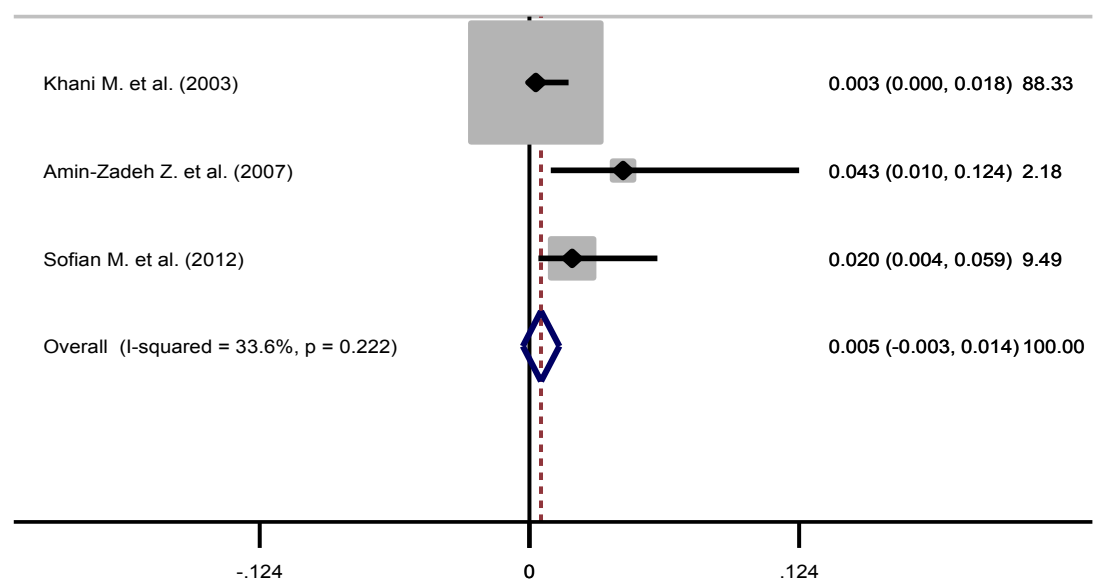

Figure 4. Forest plot showing prevalence of HBV/HIV comorbidities in the Iranian high risk group

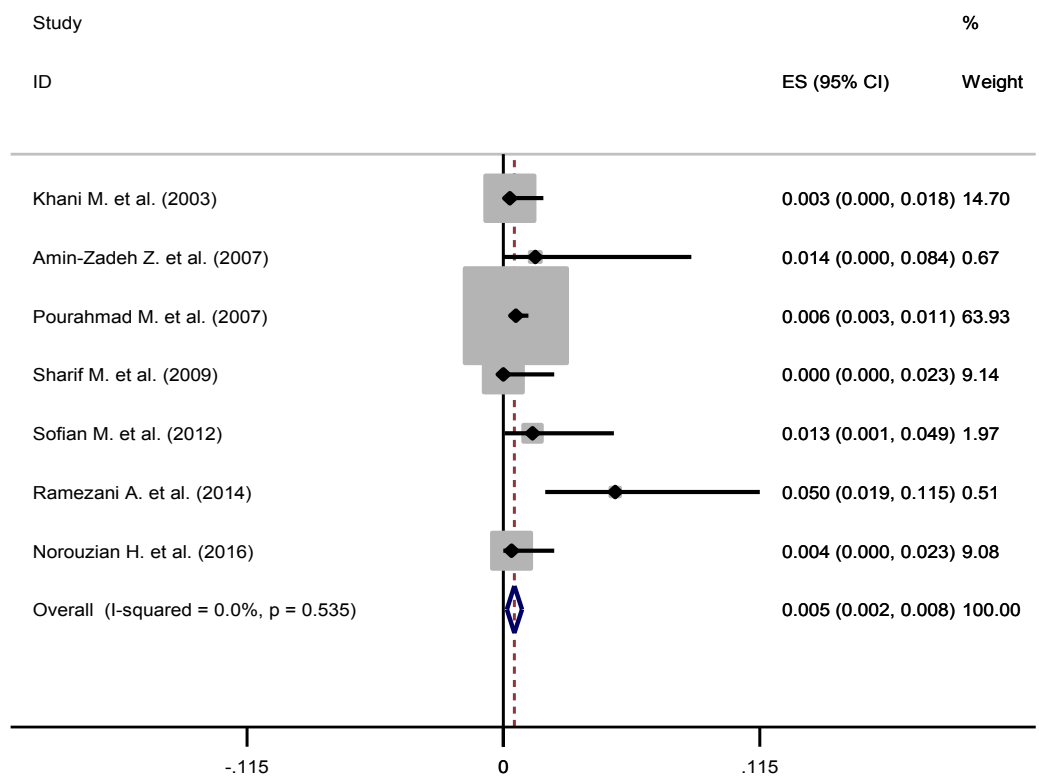

Figure 5. Forest plot showing prevalence of $\mathrm{HBV} / \mathrm{HCV} / \mathrm{HIV}$ comorbidities in the Iranian high risk group 
Review Article | HIV, HBV \& HCV co-infections in high risk groups

Table 4. Subgroup meta-analysis based on time periods

\begin{tabular}{llccccccc}
$\begin{array}{c}\text { Type of co- } \\
\text { morbidity }\end{array}$ & Time period & $\begin{array}{c}\text { No. of } \\
\text { studies }\end{array}$ & $\begin{array}{c}\text { Meta -analysis } \\
\text { Pooled } \\
\text { estimate }\end{array}$ & $95 \% \mathrm{CI}$ & $P$ & Statistic & $\mathbf{I}^{2}$ & $P$ \\
HBV/HCV & $2003-2009$ & 5 & $1.0 \%$ & $0.1-1.9$ & 0.031 & 5.43 & $26.3 \%$ & 0.246 \\
& $2010-2016$ & 4 & $2.2 \%$ & $0.3-4.1$ & 0.026 & 10.39 & $71.1 \%$ & 0.016 \\
HCV/HIV & $2003-2009$ & 4 & $8.5 \%$ & $1.9-15.0$ & 0.011 & 32.27 & $90.7 \%$ & 0.001 \\
& $2010-2016$ & 6 & $21.0 \%$ & $0-49.1$ & 0.144 & 5205 & $99.9 \%$ & 0.001 \\
HBV/HIV & $2003-2009$ & 2 & $1.3 \%$ & $0-4.6$ & 0.462 & 1.85 & $46.0 \%$ & 0.174 \\
& $2010-2016$ & 1 & $2.0 \%$ & $0-4.7$ & 0.159 & 0.00 & $0 \%$ & - \\
HBV/HCV / & $2003-2009$ & 4 & $0.5 \%$ & $0.1-0.8$ & 0.013 & 1.18 & $0 \%$ & 0.757 \\
HIV & $2010-2016$ & 3 & $1.2 \%$ & $0-3.1$ & 0.190 & 3.64 & $45.1 \%$ & 0.162 \\
\hline
\end{tabular}

\section{Discussion}

Despite decades of countrywide preventive strategies aimed to reduce the burden of main blood-borne infections, $\mathrm{HBV}$ and $\mathrm{HCV}$ are still two major causes of morbidity and mortality in HIV-infected individuals in Iran. Most characteristically, the natural history of HBV and $\mathrm{HCV}$ related liver disease and progression to hepatocellular carcinoma (HCC) is accelerated due to HIV co-infection (28). Determining the prevalence of HCV/HIV, HBV/HIV and triple coinfections in Iranian high-risk groups could be helpful to develop more effective interventions against aforementioned blood-borne viruses. The results of our study demonstrated that in Iranian high-risk groups including IDUs and prisoners, one in six HIV positive patients were concurrently suffering from HCV infection. According to recently published global metaanalysis, the prevalence of HCV/HIV coinfection is highest among people who inject drugs (PWID) as compared with other highrisk groups and the general population (29). In global estimates of $\mathrm{HCV} / \mathrm{HIV}$ co-infection, the greatest burden belongs to Eastern Europe and Central Asia due to the large HIV-infected population of PWID (29). Our findings confirm previously published evidence from Iran on the seriousness of $\mathrm{HCV} / \mathrm{HIV}$ co-infection in PWID and prisoners. Bagheri Amiri et al., in their recent systematic review study, reported that HCV/HIV co-infection prevalence was 10.95\% in Iranian PWID and $1.71 \%$ in Iranian prisoners (30). Our results are close to what they reported if we estimate the prevalence in each high-risk group separately after excluding the Alipour et al. study (31). The prevalence of HCV/HIV co- infection in the Alipour et al. study was very high (78\%). When we excluded the aforementioned study after sensitivity analysis, the pooled prevalence of HCV/HIV co-infection decreased considerably. Currently, health policy makers in Iran have given so much attention to HIV, while failing to provide proper care to curable comorbidities for example HCV.

In the present study, the pooled prevalence of HBV/HIV co-infection in Iranian high risk groups was $0.5 \%$. Matthews et al., in their recent review study, reported that prevalence of HIV-HBV co-infection were $1.1 \%-35.7 \%$ in sub-Saharan African cohorts (28). In addition, Agyeman et al., in their recently published metaanalysis reported $13.6 \%$ prevalence rate for HIV-HBV co-infection in Ghana (32). HBV/HIV co-infection is regarded as a particular challenge in Sub-Saharan Africa due to high prevalence of HIV and high HBV endemicity. Our results are inconsistent with a recently published study from Iran, which reported $1.8 \%$ and $0.13 \%$ prevalence rate for HBV-HIV co-infection among injecting drug users and prisoners, respectively. It should be noted that subgroup analysis based on time period showed that our results was close to the findings of the aforementioned study (30).

Triple infection with HIV, HBV and HCV has clinically more unfavorable consequences than mono- or dual infections (33). This scenario is uncommon globally and in sub-Saharan Africa (28). In most Sub Saharan populations triple infection with HIV, HBV and HCV was reported as $\leq 1 \%(34-36)$. In the current study, pooled prevalence of triple infection with HIV, HBV and $\mathrm{HCV}$ in Iranian high risk groups was $0.5 \%$. Our results are in agreement with global reports and 
findings from Iranian high risk populations (28, 30).

A number of limitations exist in the current study that should be noted. First, there was a considerable heterogeneity between studies which we tried to resolve by subgroup analysis. Second, different types of kits were utilised for detecting HIV Ab, HCV Ab and HBs Ag which may affect the obtained results of the current systematic review. Third, occult HBV infection, which is characterised by a negative HBs Ag with detectable HBV DNA in the serum, may result in a false-negative HBs Ag test, making the HBV results more difficult to interpret.

\section{Conclusion}

Our results highlighted the seriousness of HCV/HIV co-infection in Iranian high- risk groups including IDUs and prisoners. The significance of HCV among HIV-positive patients must receive greater attention and strategic policy directions including healthcare and clinical care delivery can help to reduce resultant morbidity and mortality among Iranian high-risk groups. In addition, the increasing trend of coinfections should be alarming for policymakers. Accordingly, screenings of co-infections as an important strategy among high-risk groups will not only prevent new infection-related morbidity, but will also reduce further transmission in the community.

\section{Acknowledgements}

The authors would like to thank Dr Nedjat for her guidance.

\section{Conflict of Interest}

None.

\section{Funds}

None.

\section{Authors' Contributions}

Conception and design: AAH, EA, SK

Analysis and interpretation of the data: AAH, KM, AMB

Drafting of the article: AAH, FS, EA, SR, YM, KM, BG, AMB, SK

Critical revision of the article for important intellectual content: AAH, FS, SR, SK

Final approval of the article: AAH, FS, EA, SR, YM, KM, BG, AMB, SK

Provision of study materials or patients: YM, KM, BG

Statistical expertise: AAH, EA

Administrative, technical, or logistic support: SK

Collection and assembly of data: YM, KM, BG, AMB

\section{Correspondence}

Dr Salman Khazaei

PhD of Epidemiology (Hamadan University of Medical Sciences)

Modeling of Non-Communicable Diseases Research Center,

Hamadan University of Medical Sciences,

Hamadan, Tehran 1449614535

Iran (the Islamic Republic of).

Tel: +989181501628

Fax: (+98)8138380130

E-mails: salman.khazaei61@gmail.com,s_khazaeii@ yahoo.com

\section{References}

1. Bertozzi S, Padian NS, Wegbreit J, DeMaria LM, Feldman B, Gayle H, et al. HIV/AIDS prevention and treatment. In: Jamison DT, Breman JG, Measham AR, editors. Disease control priorities in developing countries. 2nd ed. New York: Oxford University Press; 2006.

2. Fauci AS, Morens DM. The perpetual challenge of infectious diseases. $N$ Engl $\mathrm{J}$ Med. 2012;366(5):454-461. https://doi.org/10.1056/ NEJMc1204960

3. Centers for Disease Control and Prevention. High-impact HIV prevention: CDC's approach to reducing HIV infections in the United States 2011 [Retrieved 2017]. Available from: https://www. cdc.gov/hiv/pdf/policies_nhpc_booklet.pdf 
4. Sungkanuparph S, Vibhagool A, Manosuthi W, Kiertiburanakul S, Atamasirikul K, Aumkhyan A, et al. Prevalence of hepatitis $\mathrm{B}$ virus and hepatitis $\mathrm{C}$ virus co-infection with human immunodeficiency virus in Thai patients: a tertiary-care-based study. $J$ Med Assoc Thai. 2004;87(11):1349-1354.

5. Kheirandish P, SeyedAlinaghi S, Jahani M, Shirzad H, Seyed Ahmadian M, Majidi A, et al. Prevalence and correlates of hepatitis $\mathrm{C}$ infection among male injection drug users in detention, Tehran, Iran. Journal of Urban Health. 2009;86(6):902-908. https://doi.org/10.1007/ s11524-009-9393-0

6. Heijnen M, Mumtaz GR, Abu-Raddad LJ. Status of HIV and hepatitis C virus infections among prisoners in the Middle East and North Africa: review and synthesis. $J$ Int AIDS Soc. 2016;19(1):20873. https://doi.org/10.7448/IAS. 19.1.20873

7. Bica I, McGovern B, Dhar R, Stone D, McGowan $\mathrm{K}$, Scheib R, et al. Increasing mortality due to end-stage liver disease in patients with human immunodeficiency virus infection. Clin Infect Dis. 2001;32(3):492-497. https://doi. org/10.1086/318501

8. Thio CL, Seaberg EC, Skolasky R Jr., Phair J, Visscher B, Munoz A, et al. HIV-1, hepatitis B virus, and risk of liver-related mortality in the Multicenter Cohort Study (MACS). Lancet. 2002;360(9349):1921-1926. https://doi.org/10. 1016/s0140-6736(02)11913-1

9. Rahimi-Movaghar A, Amin-Esmaeili M, Haghdoost AA, Sadeghirad B, Mohraz M. HIV prevalence amongst injecting drug users in Iran: a systematic review of studies conducted during the decade 1998-2007. Int J Drug Policy. 2012;23(4):271-278. https://doi.org/10.1016/j. drugpo.2011.09.002

10. Moher D, Liberati A, Tetzlaff J, Altman DG. Preferred reporting items for systematic reviews and meta-analyses: the PRISMA statement. Ann Intern Med. 2009;151(4):264-269.

11. Harania RS, Karuru J, Nelson M, Stebbing J. HIV, hepatitis $\mathrm{B}$ and hepatitis $\mathrm{C}$ coinfection in Kenya. AIDS. 2008;22(10):1221-1222. https://doi. org/10.1097/QAD.obo13e32830162a8
12. Patel P, Davis S, Tolle M, Mabikwa V, Anabwani G. Prevalence of hepatitis B and hepatitis C coinfections in an adult HIV centre population in Gaborone, Botswana. Am J Trop Med Hyg. 2011;85(2):390-394. https://doi.org/10.4269/ ajtmh.2011.10-0510

13. Wells GA, Shea B, O'Connell D, Peterson J, Welch $\mathrm{V}$, Losos M, et al. The Newcastle-Ottawa Scale (NOS) for assessing the quality of nonrandomised studies in meta-analyses [Internet]. [Retrieved 2018 May 31]. Available from: http://wwwohrica/ programs/clinical_epidemiology/oxfordhtm

14. Khani M, Vakili MM. Prevalence and risk factors of HIV, hepatitis B virus and hepatitis C virus infections in drug addicts among Zanjan prisoners. Arch Iran Med. 2003;6(1):1-4.

15. Azarkar Z, Sharifzadeh G, Miraki M. HBV, HCV and HIV prevalence among South Khorasan prisoners. Medical Journal of Birjand University of Medical Sciences. 2007;14(2):50-56 [Persian].

16. Zamani S, Radfar R, Nematollahi P, Fadaie R, Meshkati M, Mortazavi S, et al. Prevalence of $\mathrm{HIV} / \mathrm{HCV} / \mathrm{HBV}$ infections and drug-related risk behaviours amongst IDUs recruited through peer-driven sampling in Iran. Int $J$ Drug Policy. 2010;21(6):493-500. https://doi.org/10.1016/j. drugpo.2010.04.006

17. Pourahmad M, Javady A, Karimi I, Ataei B, Kassaeian N. Seroprevalence of and risk factors associated with hepatitis B, hepatitis $\mathrm{C}$, and human immunodeficiency virus among prisoners in Iran. Infect Dis Clin Pract. 2007;15(6):368-372. https://doi.org/10.1097/ IPC.obo13e318142ce16

18. Aminzadeh Z, Sarhangi-poor KA. Sero epidemiology of HIV, HBV, HCV and syphilis among hospitalized IDUs in LoghmanHakim Hospital. Iranian $J$ Med Microbiol. 2007;1(3):53-56 [Persian].

19. Alavi SM, Alavi L. Seroprevalence study of HCV among hospitalized intravenous drug users in Ahvaz, Iran (2001-2006). J Infect Public Health. 2009;2(1):47-51. https://doi.org/10.1016/j.jiph. 2009.01.001

20. Sharif M, Sherif A, Sayyah M. Frequency of HBV, HCV and HIV infections among hospitalized injecting drug users in Kashan. Indian $J$ Sex Transm Dis. 2009;30(1):28-30. https://doi. org/10.4103/0253-7184.55477 
21. Hosseini M, SeyedAlinaghi S, Kheirandish $\mathrm{P}$, Javid GE, Shirzad H, Karami N, et al. Prevalence and correlates of co-infection with Human Immunodeficiency Virus and hepatitis $\mathrm{C}$ virus in male injection drug users in Iran. Arch Iran Med. 2010;13(4):318-323. https://doi.org/10.10134/ AIM.0012

22. Sofian M, Aghakhani A, Banifazl M, Azadmanesh K, Farazi AA, McFarland W, et al. Viral hepatitis and HIV infection among injection drug users in a central iranian city. $J$ Addict Med. 2012;6(4):292-296. https://doi.org/10.1097/ ADM.obo13e3182659928

23. Nokhodian Z, Meshkati M, Adibi P, Ataei B, Kassaian N, Yaran M, et al. Hepatitis C among intravenous drug users in Isfahan, Iran: a study of seroprevalence and risk factors. Int $J$ Prev Med. 2012;Special Issue:S131-S138.

24. Ziaee M, Sharifzadeh G, Namaee MH, Fereidouni M. Prevalence of HIV and hepatitis B, C, D infections and their associated risk factors among prisoners in Southern Khorasan Province, Iran. Iran J Public Health. 2014;43(2):229-234.

25. Ramezani A, Amirmoezi R, Volk JE, Aghakhani A, Zarinfar N, McFarland W, et al. HCV, HBV, and HIV seroprevalence, coinfections, and related behaviors among male injection drug users in Arak, Iran. AIDS Care-Psychological and SocioMedical Aspects of AIDS/HIV. 2014;26(9):11221126. https://doi.org/10.1080/09540121.2014.88 2485

26. Norouzian H, Gholami M, Shakib P, Goudarzi G, Ghobadian Diali H, Rezvani A. Prevalence of HCV infections and co-infection with HBV and HIV and associated risk factors among addicts in Drug Treatment Centers, Lorestan Province, Iran. Int J High Risk Behav Addict. 2016;5(1):e25028. https://doi.org/10.5812/ijhrba.25028

27. Alipour A, Haghdoost AA, Sajadi L, Zolala F. HIV prevalence and related risk behaviours among female partners of male injecting drugs users in Iran: results of a bio-behavioural survey, 2010. Sex Transm Infect. 2013;89(Suppl 3):iii41iii44. https://doi.org/10.1136/sextrans-2013-051 201

28. Matthews PC, Geretti AM, Goulder PJ, Klenerman P. Epidemiology and impact of HIV coinfection with hepatitis B and hepatitis C viruses in subSaharan Africa. J Clin Virol. 2014;61(1):20-33. https://doi.org/10.1016/j.jcv.2014.05.018
29. Platt L, Easterbrook P, Gower E, McDonald B, Sabin K, McGowan C, et al. Prevalence and burden of $\mathrm{HCV}$ co-infection in people living with HIV: a global systematic review and metaanalysis. Lancet Infect Dis. 2016;16(7):797-808. https://doi.org/10.1016/S1473-3099(15)00485-5

30. Bagheri Amiri F, Mostafavi E, Mirzazadeh A. HIV, $\mathrm{HBV}$ and HCV coinfection prevalence in Iran-a systematic review and meta-analysis. PLOS ONE. 2016;11(3):e0151946. https://doi.org/10.1371/ journal.pone.0151946

31. Alipour A, Rezaianzadeh A, Hasanzadeh J, Rajaeefard A, Davarpanah MA, Hasanabadi M. High prevalence of HCV coinfection in HIVinfected individuals in Shiraz, Islamic Republic of Iran. East Mediterr Health J. 2013;19(12):975981.

32. Agyeman AA, Ofori-Asenso R. Prevalence of HIV and hepatitis B coinfection in Ghana: a systematic review and meta-analysis. AIDS Res Ther. 2016;13:23. https://doi.org/10.1186/s12981-0160107-X

33. Forbi JC, Gabadi S, Alabi R, Iperepolu HO, Pam $\mathrm{CR}$, Entonu PE, et al. The role of triple infection with hepatitis $\mathrm{B}$ virus, hepatitis $\mathrm{C}$ virus, and human immunodeficiency virus (HIV) type-1 on CD4+ lymphocyte levels in the highly HIV infected population of North-Central Nigeria. Mem Inst Oswaldo Cruz. 2007;102(4):535537. https://doi.org/10.1590/s0074-02762007 005000025

34. Tremeau-Bravard A, Ogbukagu IC, Ticao CJ, Abubakar JJ. Seroprevalence of hepatitis B and $\mathrm{C}$ infection among the HIV-positive population in Abuja, Nigeria. Afr Health Sci. 2012;12(3):312317 .

35. Harania RS, Karuru J, Nelson M, Stebbing J. HIV, hepatitis B and hepatitis C coinfection in Kenya. Aids. 2008;22(10):1221-1222. https://doi.org/ 10.1097/QAD.obo13e32830162a8

36. Patel P, Davis S, Tolle M, Mabikwa V, Anabwani G. Prevalence of hepatitis B and hepatitis C coinfections in an adult HIV centre population in Gaborone, Botswana. Am J Trop Med Hyg. 2011;85(2):390-394. https://doi.org/10.4269/ ajtmh.2011.10-0510 